\title{
Using respiration quotients to track changing sources of soil respiration seasonally and with experimental warming
}

\author{
Caitlin Hicks Pries $^{1,2}$, Alon Angert ${ }^{3}$, Cristina Castanha ${ }^{2}$, Boaz Hilman $^{3, a}$, and Margaret S. Torn ${ }^{2}$ \\ ${ }^{1}$ Department of Biological Sciences, Dartmouth College, Hanover, NH 03755, USA \\ ${ }^{2}$ Climate and Ecosystem Science Division, Earth and Environmental Science Area, \\ Lawrence Berkeley National Laboratory, Berkeley, CA 94720, USA \\ ${ }^{3}$ Institute of Earth Sciences, the Hebrew University of Jerusalem, Givat Ram, Jerusalem 91904, Israel \\ ${ }^{a}$ currently at: Department of Biogeochemical Processes, Max Planck Institute for Biogeochemistry, Jena 07745, Germany
}

Correspondence: Caitlin Hicks Pries (caitlin.pries@dartmouth.edu)

Received: 7 June 2019 - Discussion started: 28 June 2019

Revised: 9 March 2020 - Accepted: 28 April 2020 - Published: 17 June 2020

\begin{abstract}
Developing a more mechanistic understanding of soil respiration is hampered by the difficulty in determining the contribution of different organic substrates to respiration and in disentangling autotrophic-versus-heterotrophic and aerobic-versus-anaerobic processes. Here, we use a relatively novel tool for better understanding soil respiration: the apparent respiration quotient (ARQ). The ARQ is the amount of $\mathrm{CO}_{2}$ produced in the soil divided by the amount of $\mathrm{O}_{2}$ consumed, and it changes according to which organic substrates are being consumed and whether oxygen is being used as an electron acceptor. We investigated how the ARQ of soil gas varied seasonally, by soil depth, and by in situ experimental warming $\left(+4{ }^{\circ} \mathrm{C}\right)$ in a coniferousforest whole-soil-profile warming experiment over 2 years. We then compared the patterns in ARQ to those of soil $\delta^{13} \mathrm{CO}_{2}$. Our measurements showed strong seasonal variations in $\mathrm{ARQ}$, from $\approx 0.9$ during the late spring and summer to $\approx 0.7$ during the winter. This pattern likely reflected a shift from respiration being fueled by oxidized substrates like sugars and organic acids derived from root and root respiration during the growing season to more reduced substrates such as lipids and proteins derived from microbial necromass during the winter. This interpretation was supported by $\delta^{13} \mathrm{CO}_{2}$ values, which were lower, like lipids, in the winter and higher, like sugars, in the summer. Furthermore, experimental warming significantly changed how both ARQ and $\delta^{13} \mathrm{CO}_{2}$ responded to soil temperature. Wintertime ARQ and $\delta^{13} \mathrm{CO}_{2}$ values were higher in heated than in control plots, probably due to the warming-driven increase in microbial
\end{abstract}

activity that may have utilized oxidized carbon substrates, while growing-season values were lower in heated plots. Experimental warming and phenology change the sources of soil respiration throughout the soil profile. The sensitivity of ARQ to these changes demonstrates its potential as a tool for disentangling the biological sources contributing to soil respiration.

\section{Introduction}

Despite making extensive measurements of soil respiration (Bond-Lamberty and Thomson, 2010), scientists lack methods to disentangle the processes underlying, and substrates contributing to, soil respiration, which hampers predictions of terrestrial carbon cycle responses to global change (Phillips et al., 2017). Mechanistic uncertainty surrounding soil respiration is partly responsible for the $1000 \mathrm{Pg}$ spread in model predictions of end-of-century terrestrial carbonclimate feedbacks (Friedlingstein et al., 2013). Soil respiration is the flux of $\mathrm{CO}_{2}$ from the soil surface to the atmosphere, which is dominated by autotrophic respiration from plant roots and heterotrophic respiration from soil microbes. Heterotrophic respiration, which has increased globally over the past 3 decades (Bond-Lamberty et al., 2018), is itself the sum of various processes using different sources of energy. For example, microbes consume different organic substrates depending on what molecules are accessible and whether the microbes are living in the rhizosphere or bulk soil, and mi- 
Table 1. Respiration quotients (RQs; the inverse of reported oxidative ratios, which are based on elemental analyses) and relative isotopic enrichment of common molecules and substrates for respiration found in soils. The most common RQ value is listed, followed by the range of potential RQ values in parentheses. The apparent respiration quotient is based on the simultaneous measurement of soil $\mathrm{CO}_{2}$ and $\mathrm{O}_{2}$.

\begin{tabular}{lrr}
\hline Molecule & $\mathrm{RQ}^{\mathrm{a}}$ & $\begin{array}{l}\delta^{13} \mathrm{C} \text { (relative } \\
\text { to bulk leaf) }\end{array}$ \\
\hline Organic acids & $1.4(0.97-4.2)$ & +0.75 \\
Sugars & 1.0 & $+1.5-2$ \\
Phenolics & $0.95(0.92-1.3)$ & $\mathrm{NA}$ \\
Proteins & $0.77(0.67-1.01)$ & +1 \\
Lignin & $0.88(0.88-0.94)$ & -3 \\
Lipids & $0.73(0.68-0.80)$ & -4 \\
\hline
\end{tabular}

a Data from Masiello et al. (2008). ${ }^{\mathrm{b}}$ Data from Bowling et al. (2008).

crobes utilize different terminal electron acceptors depending on $\mathrm{O}_{2}$ availability in the microsites in which they reside (Keiluweit et al., 2016; Liptzin et al., 2011). The electron donors (the organic substrates) and the electron acceptors used by soil microbes during respiration cannot be resolved by measuring the $\mathrm{CO}_{2}$ flux alone. Previous studies have used measurements of $\delta^{13} \mathrm{C}$ to partition respiration into autotrophic and heterotrophic components (e.g., Dorrepaal et al., 2009), radiocarbon to partition respiration sources by age (e.g., Trumbore, 2000), or both isotopes in combination to more finely separate respiration among sources (e.g., Hicks Pries et al., 2013; Hopkins et al., 2012). However, isotopes are not the only way to disentangle soil respiration's various components (Subke et al., 2006).

Our ability to understand soil respiration is limited by measuring only one-half of the respiration equation, the $\mathrm{CO}_{2}$ produced. Simultaneously measuring the $\mathrm{O}_{2}$ consumed can provide a more mechanistic understanding of the processes and substrates contributing to soil respiration (Phillips et al., 2017). The paired measurements of $\mathrm{CO}_{2}$ and $\mathrm{O}_{2}$ can be used to calculate a respiration quotient (RQ; Angert and Sherer, 2011). All organic matter has an oxidative ratio (1/RQ), which can be calculated based on an elemental analysis of its C, H, O, and N (Masiello et al., 2008). The oxidation state of carbon in carbohydrates is 0 with a corresponding RQ of 1 based on its elemental structure. More reduced energy sources such as lipids have lower RQ values $(\approx 0.73)$, the RQs of proteins range from 0.67 to 1 , and more oxidized sources such as organic acids have RQ ranges from 1 to 4 (Masiello et al., 2008; Table 1). The RQ of aerobic respiration therefore changes based on what substrates are being consumed (Dilly, 2001; Theenhaus et al., 1997). Anaerobic respiration increases RQ to values greater than 1 , as electron acceptors like $\mathrm{Fe}(\mathrm{III})$ and $\mathrm{NO}_{3}^{-}$replace $\mathrm{O}_{2}$. Thus, RQ can help differentiate between the electron donors (organic substrates) and terminal electron acceptors used during soil res- piration. We will refer to the "apparent" respiration quotient (ARQ) because not all ecosystem $\mathrm{CO}_{2}$ or $\mathrm{O}_{2}$ fluxes are due to respiratory processes (Angert and Sherer, 2011). For example, fluctuating redox conditions can lead to consumption of $\mathrm{O}_{2}$ during metal oxidation and drive ARQ below the value of the most reduced organic matter (Angert et al., 2015).

Thus far, $\mathrm{CO}_{2}: \mathrm{O}_{2}$ ratios have been primarily used to understand large-scale earth system processes, and only few studies have examined processes within ecosystems. This ratio in atmospheric samples has been used to estimate (a) the magnitude of the terrestrial carbon sink because carbon uptake by terrestrial ecosystems is balanced by $\mathrm{O}_{2}$ production, whereas ocean $\mathrm{CO}_{2}$ uptake is decoupled from $\mathrm{O}_{2}$ (Keeling, 1988; Keeling et al., 1996; Randerson et al., 2006; Worrall et al., 2013), and (b) anthropogenic impacts on the carbon cycle, based on the principle that burning of reduced fossil fuels results in a different oxidative ratio than photosynthesis and subsequent respiration of carbohydrates (Keeling, 1988). The $\mathrm{CO}_{2}: \mathrm{O}_{2}$ ratio of ecosystem-atmosphere exchanges is an essential quantity in these carbon cycle calculations. $\mathrm{CO}_{2}: \mathrm{O}_{2}$ ratios have been estimated from measurements of net ecosystem exchange of $\mathrm{CO}_{2}$ and $\mathrm{O}_{2}$ (e.g., Seibt et al., 2004) and from elemental analysis of biomass (Hockaday et al., 2015; e.g., Masiello et al., 2008), both of which are assumed to be similar over multiyear timescales. In early carbon sink calculations, the oxidative ratio of ecosystem fluxes was assumed to be 1.1 (ARQ =0.9) based on a single study of temperate soils (Severinghaus, 1995). However, the few subsequent studies examining the $\mathrm{CO}_{2}: \mathrm{O}_{2}$ ratio of soil respiration fluxes have shown that soil fluxes can deviate widely from that value.

Soil ARQ from incubations shifts as a result of temperature changes, substrate additions, and soil management. For example, the ARQ of peat soils decreased from about 1.1 to about 0.6 when temperatures increased from 0 to $20^{\circ} \mathrm{C}$, attributed to changing substrate use (Chapman and Thurlow, 1998). Glucose additions to German forest soils increased soil ARQ to 0.95-1.0 from a basal value around 0.7 (Dilly, 2001; Theenhaus et al., 1997). Soils under organic agriculture were found to have a greater ARQ (1.19) than the same soils under conventional agriculture $(0.72$; Theenhaus et al., 1997). Soil ARQ in mesocosms containing pine seedlings changed seasonally and when the pine seedlings were cut, indicating that the ratio is responsive to changes in vegetation (Andersen and Scagel, 1997; Scagel and Andersen, 1997).

Lastly, in one of the only studies using in situ measurements, soil ARQ taken from gas wells across multiple forested ecosystems ranged widely, from 0.14 to 1.23 , indicating the influence of abiotic processes that consume $\mathrm{O}_{2}$ (Angert et al., 2015). The wide range in soil ARQ values associated with different biochemical conditions indicates that the ratio has the potential to provide insight into the substrates contributing to respiration as well as into abiotic $\mathrm{O}_{2}$ consumption. Finer-scale research is needed, however, to explore ARQ values in the same soils under different condi- 
tions to learn what these values indicate about the processes and substrates contributing to soil respired $\mathrm{CO}_{2}$. Here we investigated how the ARQ of soil gas in situ varied seasonally, by soil depth, and by experimental warming in a whole-soilprofile warming experiment in a well-drained, oxygenated coniferous-forest soil (Hicks Pries et al., 2017). We characterized soil ARQ at 30 and $90 \mathrm{~cm}$ depths in the winter and growing season over 2 years and compared the patterns in ARQ to monthly patterns in soil profile $\delta^{13} \mathrm{CO}_{2}$. We hypothesized that ARQ values would change seasonally and with warming, reflecting the values of the organic carbon substrates being consumed by microbes. Like ARQ, the $\delta^{13} \mathrm{C}$ of soil $\mathrm{CO}_{2}$ is influenced by the use of different organic substrates, since more reduced substrates tend to have lower $\delta^{13} \mathrm{C}$ values (Bowling et al., 2008). By comparing ARQ values to other indicators of respiration sources, such as $\delta^{13} \mathrm{C}$, augmented by what we understand about plant allocation of carbon substrates belowground, we aim to advance the utility of ARQ as a tracer of respiration processes.

\section{Methods}

\subsection{Warming experiment}

The whole soil profile warming experiment is located at the University of California Blodgett Forest Research Station, in the Sierra Nevada foothills near Georgetown, CA, at $1370 \mathrm{~m}$ a.s.1. Mean annual precipitation is $1774 \mathrm{~mm}$, with most of it occurring from November to April, and mean annual temperature is about $12.5^{\circ} \mathrm{C}$ (Bird and Torn, 2006). The experiment is in a thinned 80-year-old stand of mixed conifers including ponderosa pine (Pinus ponderosa), sugar pine (Pinus lambertiana), incense cedar (Calocedrus decurrens), white fir (Abies concolor), and Douglas fir (Pseudotsuga menziesii). The soils are Holland series: fine loamy, mixed, superactive, mesic Ultic Haploxeralfs of granitic origin with thick, $>5 \mathrm{~cm}$ O horizons, minimal carbonates (Rasmussen et al., 2005), and a $\mathrm{pH}$ that ranges from 5.6 to 6.5 (Hicks Pries et al., 2018). The warming treatment warmed the soil $+4{ }^{\circ} \mathrm{C}$ to $1 \mathrm{~m}$ depth while maintaining the natural temperature gradient with depth and temporal variations in soil temperature as described in Hicks Pries et al. (2017). Briefly, there were three pairs of control and heated $3 \mathrm{~m}$ diameter circular plots; twenty-two $2.4 \mathrm{~m}$ long vertical resistance heater cables in metal conduit (BriskHeat, Ohio, USA) surrounded the heated plots. To compensate for surface heat loss, two concentric rings of heater cable at 1 and $2 \mathrm{~m}$ in diameter were installed $5 \mathrm{~cm}$ below the soil surface in heated plots. Unheated cables were installed similarly in control plots. Heating throughout the plot volume was generally even, ranging from 3.5 to $4.5^{\circ} \mathrm{C}$ except at $5 \mathrm{~cm}$ depth, where the heated plots were on average only $2.4 \pm 1.2^{\circ} \mathrm{C}$ warmer than the control due to a lack of aboveground heating. Soil moisture was slightly decreased in the warmed plots by an average of $1.5 \%-3.5 \%$ volumetric water content (Hicks Pries et al., 2017).

\subsection{Sample collection and analysis}

Dataloggers (CR1000, Campbell Scientific, Utah, USA) continuously recorded soil temperature and moisture at $30 \mathrm{~min}$ intervals. Temperature was monitored at 5, 15, 30, 50, 75, and $100 \mathrm{~cm}$ depths at a radial distance of $0.75 \mathrm{~m}$ from the center of each plot. Temperature probes consisted of thermistors (Omega 44005) epoxied to PVC rods, placed inside thin-walled steel conduit. To monitor soil moisture, we used an EnviroSCAN (Sentek, Australia) probe fitted with capacitance sensors at $10,30,50$, and $90 \mathrm{~cm}$ at a radial distance of $0.75 \mathrm{~m}$ from the center of each plot. We calibrated the soil moisture measurements by comparing the sensor values at each depth to the volumetric water content measured in nearby (within $0.5 \mathrm{~m}$ ) soil cores that were sampled five times over 2 years.

Each of the six plots has a set of gas wells at 15, 30, 50,75 , and $90 \mathrm{~cm}$. The gas wells were $6.35 \mathrm{~mm}$ diameter stainless-steel tubes inserted into the soil at a $45^{\circ}$ angle to the desired depth and topped with straight swage pipe fittings (Swagelok, Ohio, USA) with septa. For $\mathrm{CO}_{2}$ and $\delta^{13} \mathrm{CO}_{2}$ measurements, samples were collected from the wells with a syringe on a nearly monthly basis from March 2014 to June 2017 (32 months total) and always during morning hours. After clearing the headspace in each well, a $25 \mathrm{~mL}$ gas sample was transferred to an evacuated $20 \mathrm{~mL}$ septum-topped glass vial. For analysis, $5 \mathrm{~mL}$ samples were injected into the small sample isotope module of a cavity ring-down spectrometer (CRDS, Picarro, Santa Clara, California), where they were diluted with ultra-zero air (without $\mathrm{CO}_{2}$ ). A fourpoint calibration curve ranging from 2000 to $20000 \mathrm{ppm}$ $\left(\delta^{13} \mathrm{C}=-26.7 \%\right.$ ) was used to calculate the $\mathrm{CO}_{2}$ concentration from the CRDS data and to correct for mass dependency of the $\delta^{13} \mathrm{C}$ measurement.

In July 2015; February, April, and August 2016; and March and June 2017, we collected additional samples from the 30 (except July 2015) and $90 \mathrm{~cm}$ gas wells into $13 \mathrm{~mL}$ flasks equipped with O-ring valves (LouwersHanique, Hapert, Netherlands) to simultaneously measure $\mathrm{CO}_{2}$ and $\mathrm{O}_{2}$ concentrations in order to calculate ARQ. The flasks were analyzed in the laboratory at the Hebrew University by a closed system (the Hampadah; Hilman and Angert, 2016). This fully automated system uses an infrared gas analyzer (IRGA) for $\mathrm{CO}_{2}$ measurement (LI 840A, LI-COR, Lincoln, NE, USA) and a fuel-cell-based analyzer (FC-10, Sable Systems International, Las Vegas, NV, USA) for measuring $\mathrm{O}_{2}$. The flasks were analyzed within 2-3 weeks of collection.

In June 2017, we also ran a set of short $(3 \mathrm{~h})$ incubations of root-free soil and of excised roots collected adjacent to the experimental plots. We collected four mineral soil cores with a $5 \mathrm{~cm}$ diameter hammer corer, separated the cores into 0-20 and $20-40 \mathrm{~cm}$ depths, and removed roots $>1 \mathrm{~mm}$ diameter. 
Roots were collected from four $25 \mathrm{~cm} \times 25 \mathrm{~cm} \times 25 \mathrm{~cm}$ soil pits. We rinsed roots with water to remove soil and blotted them dry before placing them into mason jars. The root-free soil was also placed into mason jars, and both sets of mason jars were flushed with ambient, outside air. After a $3 \mathrm{~h}$ incubation of the root samples and a $21 \mathrm{~h}$ incubation of the soil samples, the headspace was sampled for $\mathrm{CO}_{2}$ and $\mathrm{O}_{2}$ and analyzed as described above. Incubations were run at room temperature, which was similar to the field temperature at the time of collection.

\subsection{Sample calculations and statistics}

To calculate ARQ, we used Eq. (1) from Angert et al. (2015):

$\mathrm{ARQ}=-0.76 \frac{\Delta \mathrm{CO}_{2}}{\Delta \mathrm{O}_{2}}$,

where ARQ is the apparent respiratory quotient, $\Delta \mathrm{CO}_{2}$ (ppmv) is the difference between $\mathrm{CO}_{2}$ concentrations in the soil pore-space gas and ambient (i.e., 0.5 to $1 \mathrm{~m}$ a.g.l.) samples, $\Delta \mathrm{O}_{2}$ (ppmv) is the difference of the soil pore-space $\mathrm{O}_{2}$ concentration and ambient $\mathrm{O}_{2}$ concentration, and 0.76 is the ratio of $\mathrm{CO}_{2}$ to $\mathrm{O}_{2}$ diffusivity in air (Massman, 1998). The negative sign is for convenience, so the ARQ value will typically be positive because the difference in $\mathrm{O}_{2}$ concentration is always negative. For the jar incubations we used the same equation without the 0.76 factor. Ambient $\mathrm{CO}_{2}$ concentrations were measured in the field at the time of sampling with the CRDS, while the ambient $\mathrm{O}_{2}$ concentration was assumed to be $20.95 \%$ (Rumble, 2019). To relate the $\delta^{13} \mathrm{C}$ value of soil pore-space $\mathrm{CO}_{2}$ to the $\delta^{13} \mathrm{C}$ of $\mathrm{CO}_{2}$ production, we corrected the pore-space $\delta^{13} \mathrm{C}$ value for diffusion, since ${ }^{13} \mathrm{C}$ diffuses slower in air than ${ }^{12} \mathrm{C}$, and thus the measured value does not accurately represent the value of production. For the correction, we used Eq. (2) from Bowling et al. (2015):

$\delta_{\text {production }}=\frac{C_{\mathrm{s}}\left(\delta_{\mathrm{s}}-4.4\right)-C_{\mathrm{a}}\left(\delta_{\mathrm{a}}-4.4\right)}{1.0044\left(C_{\mathrm{s}}-C_{\mathrm{a}}\right)}$,

where $C_{\mathrm{s}}$ is the soil pore-space $\mathrm{CO}_{2}$ concentration (ppmv), $\delta_{\mathrm{s}}$ $(\%)$ is the isotopic composition of soil pore-space $\mathrm{CO}_{2}$, and $C_{\mathrm{a}}$ and $\delta_{\mathrm{a}}$ are the $\mathrm{CO}_{2}$ concentration and isotopic composition of ambient air, respectively. The ambient $\mathrm{CO}_{2}$ concentrations and $\delta^{13} \mathrm{C}$ values needed for these corrections were measured in the field at the time of sampling with the CRDS.

To investigate the effects of season, warming treatment, and soil depth on ARQ and $\delta^{13} \mathrm{C}$, we ran multiple regressions in $\mathrm{R}$ ( $\mathrm{R}$ Development Core Team, 2019). Because ARQ was not sampled from both depths on all dates, we ran separate regressions for each depth $(30$ and $90 \mathrm{~cm}$ ) and then ran a regression that included a depth effect while dropping the first sampling date. In all regressions, treatment and sampling date (as a factor) were fixed effects. Following Zuur et al. (2009), we used a full model with all fixed effects and their interactions to optimize the random effects and autocorrelation structure based on the Akaike information criterion (AIC).
For both versions, we used the individual gas well as a random effect, and a temporal autocorrelation did not improve the model, nor did an autocorrelation function graph indicate that one was needed. We chose the significant fixed effects by performing a series of pairwise model comparisons using AIC and the $F$ test, dropping the least significant variables each time until only variables that improved the model fit remained. The $p$ values reported are those from the $t$ tests of the summary.lme function of best-fit model. We report conditional $R^{2}$ values calculated using the rsquared command in the piecewiseSEM package.

To investigate seasonal patterns in $\delta^{13} \mathrm{CO}_{2}$, we had more data in terms of both length of time and temporal density of sampling and were thus able to treat the month as a continuous variable. We fit a sine function and tested models including the first and second harmonics of the month effect as well as linear fixed effects of depth, treatment, and a depth-by-treatment interaction. Graphical exploration indicated that the sinusoidal pattern differed slightly by year, so we also added a year effect to the second harmonic of the month effect. As above, we used the full fixed-effect model to test the best random and autocorrelation structure. Individual gas well depth was used as a random effect, and a correlation structure did not improve the model.

To test relationships between ARQ and $\delta^{13} \mathrm{CO}_{2}$, and both ARQ and $\delta^{13} \mathrm{CO}_{2}$ individually versus soil temperature and VWC (volumetric water content), we ran mixed-model regressions with the individual gas well as a random effect. For the soil-climate relationships, we used the AIC and the $F$ test to investigate whether the warming treatment and its interaction with soil temperature or VWC were significant fixed effects. We tested the need for autocorrelation structures based on AIC, and none improved the models. For all models, we graphically checked the residuals for violations of normality and heterogeneity of variance. For $\delta^{13} \mathrm{CO}_{2}$ analyses, we dropped the $15 \mathrm{~cm}$ depths due to their unusually low $\delta^{13} \mathrm{C}$ value $(<-32 \%$ ) after correction (Eq. 2), which indicated potential intrusion of atmospheric air during sampling that led to an overcorrection. We used one-way ANOVA to compare the ARQ of soil and root incubations and the ARQ of two soil depths we incubated. All statistics were performed in $\mathrm{R}$ version 3.4.1, and regressions were done using the lme function (R Development Core Team, 2019).

\section{Results}

Both ARQ and $\delta^{13} \mathrm{CO}_{2}$ had similar, strong seasonal patterns (Fig. 1a and b). ARQ values were higher during the growing season $(0.89 \pm 0.01, n=42)$ and lower during the winter $(0.70 \pm 0.02, n=23)$. In ARQ regression analyses for both depths, there was a significant effect of date $(p<0.0001$, $n=59$ ), with February 2016 and March 2017 differing significantly from July 2015 (90 cm only), April and August 2016, and June 2017. Similarly, $\delta^{13} \mathrm{C}$ was higher during the 

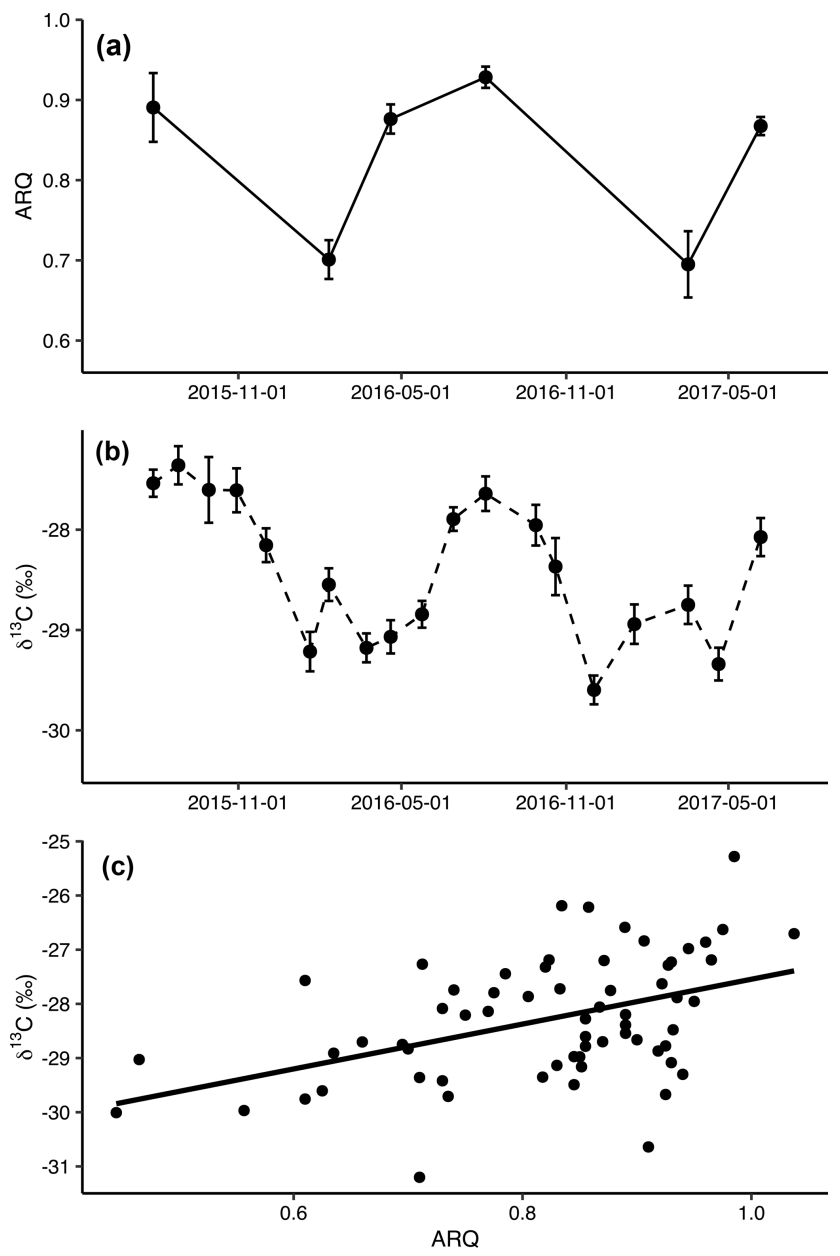

Figure 1. Mean $( \pm \mathrm{SE})$ apparent respiration quotient (ARQ, $n=12$ except $n=6$ for July 2015; a) and corrected $\delta^{13} \mathrm{CO}_{2}(n=24$ per date; b) in soil pore air averaged across all depths and treatments by sampling month. The relationship between ARQ and $\delta^{13} \mathrm{CO}_{2}$ values during the months when they were sampled simultaneously (c). The line shows the fit of a linear regression $(p<0.0001, n=64$, $\left.R^{2}=0.20\right)$.

summer (June through October, $-27.97 \pm 0.06, n=311$ ) and lower during the winter and spring (November through May, $-29.01 \pm 0.04, n=447)$. While individual dates were not compared statistically for $\delta^{13} \mathrm{CO}_{2}$, the vast improvement in model fit using month as a sine function instead of a linear function or factor $(\triangle \mathrm{AIC}=114)$ is strong statistical evidence for a seasonal effect (Fig. 2b). ARQ and $\delta^{13} \mathrm{CO}_{2}$ were significantly related according to the mixed-effect regression model (Fig. 1c; $p<0.0001, n=64, R^{2}=0.20$ ). However, the patterns in ARQ and $\delta^{13} \mathrm{CO}_{2}$ did not match during April.

Both ARQ and $\delta^{13} \mathrm{CO}_{2}$ differed by warming treatment (Fig. 2) and by depth (Table 2). For the ARQ of $30 \mathrm{~cm}$ depths, there was a significant treatment-by-date interaction ( $p=0.051, n=30)$ whereby heated plots had greater ARQ values during the winter months (February 2016 and
Table 2. The mean $\pm \mathrm{SE}$ (number of samples) of corrected $\delta^{13} \mathrm{CO}_{2}$ and ARQ of soil pore-space by depth averaged over all time points.

\begin{tabular}{lrr}
\hline $\begin{array}{l}\text { Depth } \\
(\mathrm{cm})\end{array}$ & $\delta^{13} \mathrm{CO}_{2}(\% \circ)$ & ARQ \\
\hline 30 & $-29.0 \pm 0.09(191)$ & $0.84 \pm 0.02(30)$ \\
50 & $-28.6 \pm 0.08(190)$ & \\
70 & $-28.4 \pm 0.07(191)$ & \\
90 & $-28.3 \pm 0.08(186)$ & $0.81 \pm 0.02(35)$ \\
\hline
\end{tabular}

March 2017; Fig. 2a). For the ARQ of $90 \mathrm{~cm}$ depths, the best-fit model did not include a significant treatment effect or treatment-by-date interaction (Fig. 2a; $n=35$ ). For ${ }^{13} \mathrm{CO}_{2}$ across all depths, treatment was a significant effect ( $p=0.0065, n=758$ ), with warmed soil on average having a slightly higher $\delta^{13} \mathrm{CO}_{2}(-28.33 \pm 0.05)$ than the control soil $(-28.83 \pm 0.06$; Fig. $2 b)$. The treatment-by-depth interaction was not significant for $\delta^{13} \mathrm{CO}_{2}$ and was not included in the best-fit model. Looking at depth only (Table 2), the ARQ at $30 \mathrm{~cm}$ was marginally significantly greater than the ARQ at $90 \mathrm{~cm}$ by 0.07 units $(p=0.099, n=59)$, while $\delta^{13} \mathrm{CO}_{2}$ increased with depth, from -28.98 at $30 \mathrm{~cm}$ to -28.34 at $90 \mathrm{~cm}(p=0.0089, n=758)$.

Both ARQ and $\delta^{13} \mathrm{CO}_{2}$ showed strong relationships with soil climate that were significantly affected by the warming treatment (Fig. 3). We tested relationships with soil temperature and soil moisture individually because of the strong negative correlation between temperature and moisture in this Mediterranean climate (Pearson's $r=-0.76$ to -0.78 ). ARQ increased significantly with increasing soil temperatures $\left(p<0.0001, n=65, R^{2}=0.52\right.$; Fig. $\left.3 \mathrm{a}\right)$, with values increasing faster in control plots than in warmed plots $(p=0.0051)$. ARQ decreased with increased soil moisture ( $p<0.0001, n=60$ due to missing VWC values, $R^{2}=$ 0.24; Fig. 3b), and the decrease was faster in the control than in the warmed plots. $\delta^{13} \mathrm{CO}_{2}$ became higher with increasing soil temperatures ( $p<0.0001, n=375, R^{2}=0.33$; Fig. 3 c), with values again increasing faster in the control than in the warmed plots $(p=0.02) . \delta^{13} \mathrm{CO}_{2}$ decreased with increased soil moisture ( $p<0.0001, n=345$ due to missing VWC values, $R^{2}=0.30$; Fig. $3 \mathrm{~d}$ ), and treatment did not have a significant effect.

Our incubations of roots $(n=4)$ and of root-free soil ( $n=4$ per depth increment) indicated that heterotrophic and autotrophic respiration had significantly different ARQ values, at least during the summer when we performed the incubations. Roots had a greater ARQ $(0.87 \pm 0.03)$ than rootfree soil $(0.78 \pm 0.02$; one-way ANOVA, $p=0.029)$. Furthermore, the ARQ of the soil incubations significantly declined with depth, from $0.82 \pm 0.01$ at $0-20 \mathrm{~cm}$ to $0.74 \pm 0.02$ at $20-40 \mathrm{~cm}$ (one-way ANOVA, $p=0.0053$ ). 

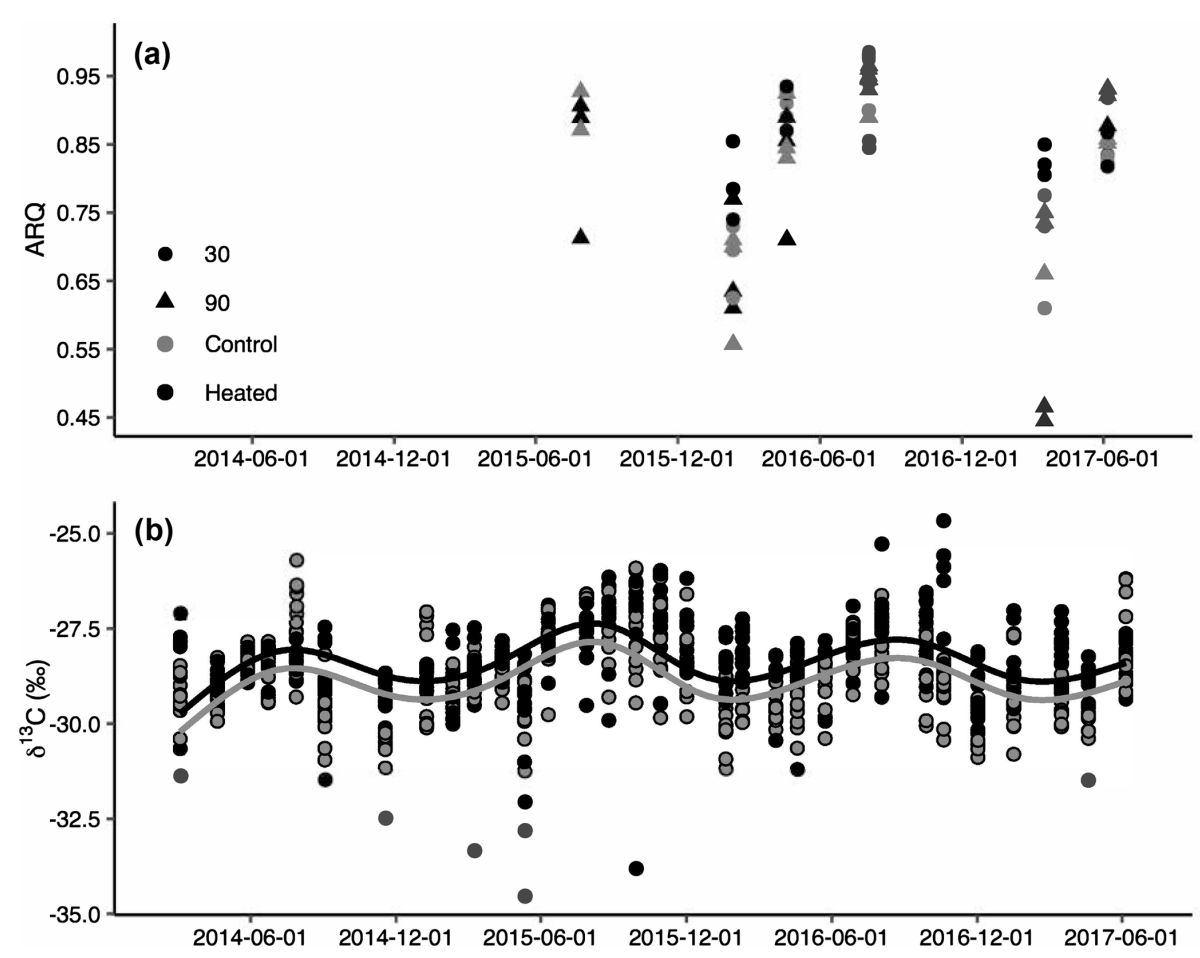

Figure 2. Apparent respiration quotient (ARQ) by sampling date for heated (black) and control (grey) treatments at $30 \mathrm{~cm}$ (circles) and $90 \mathrm{~cm}$ (triangles) depths ( $n=3$ per date and depth combination; a). ARQ differed significantly among treatments during the winter at $30 \mathrm{~cm}$. Corrected $\delta^{13} \mathrm{CO}_{2}$ for all depths $(30,50,70$, and $90 \mathrm{~cm})$ and months sampled $(\mathbf{b})$. The lines represent the predicted fit of a sinusoidal regression (see text) for an average soil depth in control (grey) and heated (black) treatments $(n=758)$.

\section{Discussion}

There are many factors that can affect ARQ; however, our evidence indicates that the strong seasonal patterns in ARQ and $\delta{ }^{13} \mathrm{CO}_{2}$ were likely driven by changes in the amount of root-derived organic substrates providing energy for heterotrophic microbial respiration and changes in the contributions of autotrophic root respiration. This interpretation is supported by previous soil ARQ studies, our incubations, and the scientific understanding of how plant carbon inputs change seasonally. The seasonal range in ARQ from $\approx 0.9$ during the growing season to $\approx 0.7$ during the winter may reflect a shift in the molecules fueling respiration from more oxidized substrates like sugars and organic acids derived from roots in the summer to more reduced substrates in the winter such as lipids and proteins derived from microbial necromass. Previous incubations found that glucose additions increased ARQ (Dilly, 2001; Theenhaus et al., 1997). Other studies attributed a decline in ARQ during the time course of incubation to the depletion of labile carbon sources (Angert et al., 2015; Severinghaus, 1995). Our short-term incubations demonstrated that root respiration has a greater ARQ than microbial respiration from root-free soils. During the growing season, root respiration and exudation increase, which should increase ARQ, as seen in our data. In the eastern US deciduous forests, root exudation rates tend to be lower in the winter and spring than in the summer and fall (Abramoff and Finzi, 2016; Phillips et al., 2008). Mass-specific fine-root respiration rates were greater during the growing season (up to $8 \mathrm{nmolCO}_{2} \mathrm{~g}^{-1} \mathrm{~s}^{-1}$ ) than in the winter $\left(<1 \mathrm{nmol} \mathrm{CO}_{2} \mathrm{~g}^{-1} \mathrm{~s}^{-1}\right)$, and total belowground carbon flux was greatest from May to October (Abramoff and Finzi, 2016). Though these root studies were not from the western United States, eddy covariance data from a coniferous forest near our study site found that primary production was greatest during the summer months, from June to midSeptember (Goldstein et al., 2000).

Beyond the results of our root and root-free soil incubations, there is additional evidence that root and rhizosphere respiration should have a greater ARQ than microbially derived respiration. For example, respiration of root tips is driven by sugar content and has an RQ of 1.0 (Saglio and Pradet, 1980). Furthermore, recent metabolomic analysis of root exudates identified sugars, carboxylic acids, amino acids, and phenolics as the main metabolites (Zhalnina et al., 2018), most of which are relatively oxidized energy sources with relatively high respiratory quotients. Thus, we would expect greater ARQ values during the summer due to higher root activity. When trees are dormant, the lack of fresh inputs from roots may lead to more recycling of organic carbon within microbial biomass, wherein proteins and lipids are the first and third largest constituents by weight, mak- 

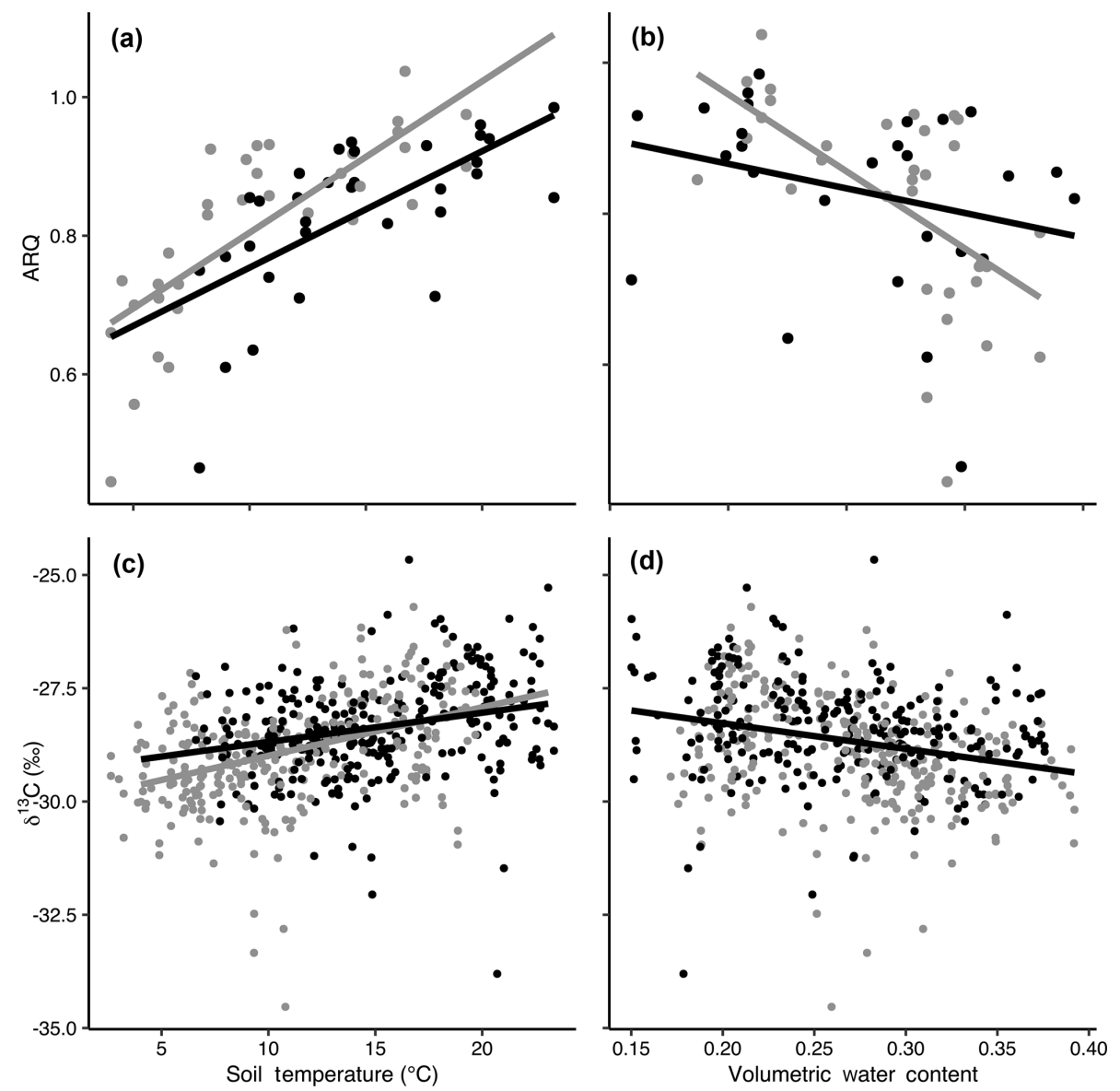

Figure 3. The relationships of apparent respiration quotient (ARQ) by soil temperature $(\mathbf{a} ; n=65)$ and soil moisture $(\mathbf{b} ; n=60)$ and $\delta^{13} \mathrm{CO}_{2}$ by soil temperature $(\mathbf{c} ; n=565)$ and soil moisture $(\mathbf{d} ; n=535)$. Gray and black points represent data from control and heated gas wells, respectively. The lines show the fit of a mixed-model regression between each variable, where individual gas well was treated as a random effect. Separate grey (control) and black (heated) lines indicate that there was a significant effect of warming treatment on the relationship between the response variable and soil temperature or volumetric water content.

ing up to $55 \%$ and from $10 \%$ to $35 \%$ of a typical bacterial cell's dry mass, respectively (Kleber and Reardon, 2017; Neidhardt, 1987). Lipids and proteins tend to be reduced and have the lowest RQ values of common organic substrates, likely explaining the lower wintertime ARQ values in our soils.

The seasonal pattern in $\delta^{13} \mathrm{CO}_{2}$ reinforces our interpretation that changes in respiration carbon sources were driving changes in ARQ. Soil $\delta^{13} \mathrm{CO}_{2}$ was more enriched in the summer and became more depleted in the winter by up to $2 \%$. In a comprehensive review of carbon isotopes in terrestrial ecosystems, Bowling et al. (2008) showed that plant lipids tend to be more depleted in ${ }^{13} \mathrm{C}$, while sugars and organic acids tend to be more enriched in ${ }^{13} \mathrm{C}$ relative to bulk leaf $\delta^{13} \mathrm{C}$. While these numbers are based on plant lipids, if we assume that microbial lipids are similarly depleted relative to other organic compounds, an increase in microbial necromass as an organic matter source relative to root-derived sources during the winter would cause the observed fluctua- tion in $\delta^{13} \mathrm{CO}_{2}$. Furthermore, a chemical fractionation of soil organic matter found that the water-soluble fraction, which includes sugars, was 3\%-4\%o more enriched than the acidinsoluble pool (Biasi et al., 2005). While the interpretation of respiration $\delta^{13} \mathrm{C}$ by itself in $\mathrm{C}_{3}$ ecosystems can be difficult due to the small per mill differences among carbon sources (e.g., Bowling et al., 2015), the simultaneous use of ARQ and ${ }^{13} \mathrm{CO}_{2}$ helps strengthen interpretations.

Seasonality encompasses changes to phenology and soil climate, among other factors. Both ARQ and $\delta^{13} \mathrm{C}$ had significant positive relationships with soil temperature. In addition to the importance of plant phenology described above, temperature could have direct effects on respiration sources. Specifically, warmer temperatures can increase root exudation rates (Yin et al., 2013) and the relative contribution of autotrophic-derived, if not directly autotrophic, respiration to total soil respiration. In two subarctic ecosystems, warming increased the proportion of ecosystem respiration derived from autotrophs (which, using natural abundance radiocar- 
bon as a tracer, included heterotrophic respiration of root exudates) relative to heterotrophs (Hicks Pries et al., 2015). However, temperatures can affect ARQ beyond changing the contributions of autotrophic sources. Lower temperatures increase the thermodynamic favorability of the oxidation of reduced carbon in compounds like lipids (LaRowe and Van Cappellen, 2011), which could also explain the decrease in ARQ values at lower temperatures. For $\delta^{13} \mathrm{C}$, it is likely that phenological changes to organic carbon sources were more important than temperature per se. Several soil incubation studies show that increases in temperature cause respired $\delta^{13} \mathrm{CO}_{2}$ to decrease by about $0.12 \% 0-0.35 \%$ or for each $1{ }^{\circ} \mathrm{C}$ rise in temperature - the opposite of the relationship we found (Andrews et al., 2000; Biasi et al., 2005; Hicks Pries et al., 2013). In these incubations, which were devoid of new organic carbon inputs, unlike in situ conditions, the shift was attributed to changes to the microbial community that affected carbon source preferences (Andrews et al., 2000; Biasi et al., 2005). Furthermore, in a Mediterranean climate, phloem sap from trees has been shown to become more enriched in ${ }^{13} \mathrm{C}$ during the summer (Merchant et al., 2010), matching our pattern in soil $\delta^{13} \mathrm{CO}_{2}$.

While ARQ and $\delta^{13} \mathrm{CO}_{2}$ increased with soil temperature, experimental warming slowed that rate of increase so that both ARQ and $\delta^{13} \mathrm{CO}_{2}$ values were generally greater in the control than in the heated treatment at the warmest soil temperature. Concurrently, during the colder months, experimental warming caused greater ARQ values (as at $30 \mathrm{~cm}$ depths in February 2016 and March 2017) and slightly higher $\delta^{13} \mathrm{CO}_{2}$ relative to the controls. The increase in ARQ and $\delta^{13} \mathrm{CO}_{2}$ with experimental warming during the colder soil temperatures of winter indicates proportionately more respiration of relatively oxidized, labile organic substrates in the heated treatment. Perhaps enhanced root growth and exudation in the heated treatment (Yin et al., 2013) could result in the increased availability of labile organic substrates, but this increase occurred in winter, when trees were less active, and was not seen during the growing season. The increase in ARQ and $\delta^{13} \mathrm{CO}_{2}$ could also be the result of preferential decomposition of more highly oxidized, labile substrates by a more active microbial population during the winter. Experimental warming increased microbial activity at all soil depths; warming increased $\mathrm{CO}_{2}$ production by $34 \%$ to $37 \%$ overall, with about $40 \%$ of the warming response occurring below $15 \mathrm{~cm}$ in the soil profile (Hicks Pries et al., 2017). A warming-induced increase in the consumption of labile substrates could lead to exhaustion of the labile pool and eventually smaller warming-induced SOC (soil organic carbon) losses, as seen at Harvard Forest (Melillo et al., 2002, 2017). In fact, the trend towards decreased ARQ and $\delta^{13} \mathrm{CO}_{2}$ values during the warmer soil temperatures of the growing season could be due to a depletion of the labile SOC pool during the winter. Another potential explanation for lower values during the growing season could be a reduction in the proportion of soil respiration derived from roots. In one warming study, root respiration was less sensitive to warming relative to heterotrophic respiration (Hartley et al., 2007). The warming treatment dried the soil slightly at Blodgett (Hicks Pries et al., 2017), which could stress roots during California's essentially rainless growing season. Future measurements of $\mathrm{CO}_{2}$ production, ARQ, and $\delta^{13} \mathrm{CO}_{2}$ in trenched and untrenched plots could help distinguish these possibilities.

Soil temperature and soil moisture were so strongly negatively correlated due to our study site's Mediterranean climate that it is difficult to separate their effects. The ARQ and $\delta^{13} \mathrm{CO}_{2}$ were negatively correlated with volumetric water content, which was greatest when soil temperatures were coldest. Volumetric water content has the potential to control ARQ in several ways. First, increased soil moisture reduces $\mathrm{O}_{2}$ availability, which could increase ARQ values $>1$, as $\mathrm{CO}_{2}$ is produced without $\mathrm{O}_{2}$ consumption. However, during our study the soil remained oxic (soil $\mathrm{O}_{2}$ averaged $20 \%$ and the minimum was $17.38 \%$ ). The negative relationship between ARQ and soil moisture indicates that anaerobic respiration was not a driver, and we only measured one ARQ value greater than 1 (1.03) during our study. However, diffusion rates slow with higher soil moisture, which could make detection of high ARQ values difficult if anoxic conditions occur within microaggregates. In anoxic microaggregates, iron (II) is produced anaerobically, which is subsequently oxidized to iron (III) as the aggregate dries and becomes aerobic, a process that consumes $\mathrm{O}_{2}$ without producing $\mathrm{CO}_{2}$, resulting in low ARQ values that can be detected as drying soils increase diffusion (Angert et al., 2015). In our soils, which tend to contain relatively high amounts of iron oxides (Rasmussen et al., 2005), iron oxidation could explain the $15 \%$ of ARQ values that were less than the reduced organic matter value of 0.7 . Lastly, since $\mathrm{CO}_{2}$ is more soluble in water than is $\mathrm{O}_{2}$, more $\mathrm{CO}_{2}$ relative to $\mathrm{O}_{2}$ is expected to dissolve in soil water, which would reduce ARQ values at higher moisture contents. However, different dissolution rates and iron oxidation do not fully explain our data, as the wide variability in ARQ values (0.44 to 0.94$)$ at high volumetric water contents $(0.27$ to 0.31$)$ can be best explained by time of year (Fig. S1 in the Supplement), which again points to phenology as the main driver; the greater ARQ values are from April and June, while the lower values are from February and March. Furthermore, there was a stronger relationship between observed and predicted ARQ in the temperature model than in the soil moisture model.

Experimental warming affected the relationship between ARQ and soil moisture. ARQ was greater in the heated treatment when soil moisture was high (winter) and lower in the heated treatment when soil moisture was low (growing season). Soil water sampled from lysimeters had a greater concentration of dissolved organic carbon in the warming treatment than in the control (unpublished data), which could deliver oxidized substrates to microbes during the winter rainy season. 
The reasons for $\delta^{13} \mathrm{CO}_{2}$ decreasing with increasing volumetric water content are not clear. Based on kinetics, we would expect that as more $\mathrm{CO}_{2}$ dissolves in water, the soil air should become enriched in ${ }^{13} \mathrm{CO}_{2}$ because dissolution discriminates against the heavy isotope, and increasingly so at lower temperatures (Zhang et al., 1995), but our data were not consistent with this explanation. Another possibility is that advective transport of atmospheric $\mathrm{CO}_{2}$ through the soil is more likely at lower soil moisture content. While intrusion of atmospheric $\mathrm{CO}_{2}$ would increase the $\delta^{13} \mathrm{C}$ of soil air, it reduces the effective diffusion fractionation to $<4.4 \%$, leading to overcorrected and thus unrealistically low $\delta^{13} \mathrm{C}$ values, of which we did have several.

Depth was the only parameter by which ARQ and $\delta^{13} \mathrm{CO}_{2}$ did not change in concert with one another. ARQ decreased with depth, while $\delta^{13} \mathrm{CO}_{2}$ increased. The decrease in ARQ with depth, which was more dramatic in the root-free soil incubations than in soil air (difference of 0.08 versus 0.03 ), is likely due to decreased plant inputs with fewer fine roots and less root exudation at depth (Hicks Pries et al., 2018; Tückmantel et al., 2017). The enrichment of soil $\delta^{13} \mathrm{CO}_{2}$ likely reflects the near-universal enrichment of soil organic carbon with depth due to catabolic carboxylation reactions (as microbial byproducts and necromass become a larger proportion of soil organic matter; Ehleringer et al., 2000; Torn et al., 2002) or the Suess effect (the continuing depletion of atmospheric $\mathrm{CO}_{2}$ over time due to the burning of fossil fuels). In our soils, there was about a $2 \%$ enrichment in bulk soil organic $\delta^{13} \mathrm{C}$ with depth (Hicks Pries et al., 2018).

\section{Conclusions}

Here we have shown, for the first time, annual patterns in the soil ARQ and how ARQ is affected by experimental warming. We inferred that seasonal patterns in ARQ were likely due to changes in the dominant substrates providing the energy for soil respiration, with root-derived sugars and organic acids being the dominant substrates during the growing season and microbial necromass being the dominant substrate during the winter. These inferences of organic substrates were supported by soil $\delta^{13} \mathrm{CO}_{2}$ measurements, which showed clear patterns despite our study system containing only $\mathrm{C}_{3}$ plants. We recognize that direct experimental evidence of how ARQ changes with sources is needed before our inferences of substrate use can be proven. However, our data indicate that ARQ measurements can help to disentangle the biological sources contributing to soil respiration and to understand how sources are shifting due to global change. This application of ARQ worked well in our soils, which were well-drained, oxygenated, and lacked carbonates. The interpretation of soil ARQ values becomes more complex if those conditions are not met (Angert et al., 2015). The autotrophic and heterotrophic source separation in our incubations indicates that ARQ has the potential to be used to parti- tion soil respiration in a similar manner to natural abundance $\delta^{13}$ C (e.g., Dorrepaal et al., 2009; Hicks Pries et al., 2013). To enable further applications of ARQ, more characterization is needed of the controls of the ratio, including incubation studies of sterile and "live" soils under aerobic and anaerobic conditions and co-located measurements of ARQ fluxes and the oxidative ratio of organic matter sources as in Masiello et al. (2008). Such future investigations will help determine whether ARQ deserves a prominent place alongside natural abundance isotopes in the ecosystem ecology and biogeochemistry toolkit.

Code and data availability. Data (https://doi.org/10.15485/ 1596312, Hicks Pries et al., 2020) are publicly available on ESS-DIVE (http://ess-dive.lbl.gov/). The $\mathrm{R}$ code used for the statistics and to generate the figures in this paper is available as a Supplement.

Supplement. The supplement related to this article is available online at: https://doi.org/10.5194/bg-17-3045-2020-supplement.

Author contributions. CHP, AA, and MST conceived of the study. Field measurements were conducted by CHP and CC. Lab analyses were conducted by CHP and BH. Statistical analyses were conducted by CHP. CHP wrote the paper, with feedback from all authors.

Competing interests. The authors declare that they have no conflict of interest.

Acknowledgements. We would like to acknowledge Rachel Porras for her assistance in running the isotopic samples and Bryan Curtis and Biao Zhu for their contributions to setting up the warming experiment.

Financial support. This research was supported as part of the Terrestrial Ecosystem Science Program by the Office of Science, Office of Biological and Environmental Research, of the US Department of Energy under grant no. DE-AC02-05CH11231.

Review statement. This paper was edited by Michael Bahn and reviewed by two anonymous referees.

\section{References}

Abramoff, R. Z. and Finzi, A. C.: Seasonality and partitioning of root allocation to rhizosphere soils in a midlatitude forest, Ecosphere, 7, e01547, https://doi.org/10.1002/ecs2.1547, 2016. 
Andersen, C. P. and Scagel, C. F.: Nutrient availability alters belowground respiration of ozone-exposed ponderosa pine, Tree Physiol., 17, 377-387, 1997.

Andrews, J. A., Matamala, R., Westover, K. M., and Schlesinger, W. H.: Temperature effects on the diversity of soil heterotrophs and the $\delta^{13} \mathrm{C}$ of soil-respired $\mathrm{CO}_{2}$, Soil Biol. Biochem., 32, 699-706, 2000.

Angert, A. and Sherer, Y.: Determining the relationship between tree-stem respiration and $\mathrm{CO}_{2}$ efflux by $\delta \mathrm{O}_{2} / \mathrm{Ar}$ measurements, Rapid Commun. Mass Sp., 25, 1752-1756, https://doi.org/10.1002/rcm.5042, 2011.

Angert, A., Yakir, D., Rodeghiero, M., Preisler, Y., Davidson, E. A., and Weiner, T.: Using $\mathrm{O}_{2}$ to study the relationships between soil $\mathrm{CO}_{2}$ efflux and soil respiration, Biogeosciences, 12, 2089-2099, https://doi.org/10.5194/bg-12-2089-2015, 2015.

Biasi, C., Rusalimova, O., Meyer, H., Kaiser, C., Wanek, W., Barsukov, P., Junger, H., and Richter, A.: Temperature-dependent shift from labile to recalcitrant carbon sources of arctic heterotrophs, Rapid Commun. Mass Sp., 19, 1401-1408, 2005.

Bird, J. A. and Torn, M. S.: Fine roots vs. needles: a comparison of ${ }^{13} \mathrm{C}$ and ${ }^{15} \mathrm{~N}$ dynamics in a ponderosa pine forest soil, Biogeochemistry, 79, 361-382, 2006.

Bond-Lamberty, B. and Thomson, A.: A global database of soil respiration data, Biogeosciences, 7, 1915-1926, https://doi.org/10.5194/bg-7-1915-2010, 2010.

Bond-Lamberty, B., Bailey, V. L., Chen, M., Gough, C. M., and Vargas, R.: Globally rising soil heterotrophic respiration over recent decades, Nature, 560, 80, https://doi.org/10.1038/s41586018-0358-x, 2018.

Bowling, D. R., Pataki, D. E., and Randerson, J. T.: Carbon isotopes in terrestrial ecosystem pools and $\mathrm{CO}_{2}$ fluxes, New Phytol., 178, 24-40, https://doi.org/10.1111/j.1469-8137.2007.02342.x, 2008.

Bowling, D. R., Egan, J. E., Hall, S. J., and Risk, D. A.: Environmental forcing does not induce diel or synoptic variation in the carbon isotope content of forest soil respiration, Biogeosciences, 12, 5143-5160, https://doi.org/10.5194/bg-12-5143-2015, 2015.

Chapman, S. J. and Thurlow, M.: Peat respiration at low temperatures, Soil Biol. Biochem., 30, 1013-1021, https://doi.org/10.1016/S0038-0717(98)00009-1, 1998.

Dilly, O.: Microbial respiratory quotient during basal metabolism and after glucose amendment in soils and litter, Soil Biol. Biochem., 33, 117-127, https://doi.org/10.1016/S00380717(00)00123-1, 2001.

Dorrepaal, E., Toet, S., van Logtestijn, R. S. P., Swart, E., van de Weg, M. J., Callaghan, T. V., and Aerts, R.: Carbon respiration from subsurface peat accelerated by climate warming in the subarctic, Nature, 460, 616-619, https://doi.org/10.1038/nature08216, 2009.

Ehleringer, J. R., Buchmann, N., and Flanagan, L. B.: Carbon isotope ratios in belowground carbon cycle processes, Ecol. Appl., 10, 412-422, 2000.

Friedlingstein, P., Meinshausen, M., Arora, V. K., Jones, C. D., Anav, A., Liddicoat, S. K., and Knutti, R.: Uncertainties in CMIP5 Climate Projections due to Carbon Cycle Feedbacks, J. Climate, 27, 511-526, https://doi.org/10.1175/JCLI-D-12$00579.1,2013$.

Goldstein, A. H., Hultman, N. E., Fracheboud, J. M., Bauer, M. R., Panek, J. A., Xu, M., Qi, Y., Guenther, A. B., and Baugh, W.: Effects of climate variability on the carbon dioxide, water, and sensible heat fluxes above a ponderosa pine plantation in the Sierra Nevada (CA), Agr. Forest Meteorol., 101, 113-129, https://doi.org/10.1016/S0168-1923(99)00168-9, 2000.

Hartley, I. P., Heinemeyer, A., Evans, S. P., and Ineson, P.: The effect of soil warming on bulk soil vs. rhizosphere respiration, Global Change Biol., 13, 2654-2667, https://doi.org/10.1111/j.13652486.2007.01454.x, 2007.

Hicks Pries, C. E., Schuur, E. A. G., and Crummer, K. G.: Thawing permafrost increases old soil and autotrophic respiration in tundra: Partitioning ecosystem respiration using $\delta^{13} \mathrm{C}$ and $\delta^{14} \mathrm{C}$, Global Change Biol., 19, 649-661, https://doi.org/10.1111/gcb.12058, 2013.

Hicks Pries, C. E., Logtestijn, R. S., Schuur, E. A., Natali, S. M., Cornelissen, J. H., Aerts, R., and Dorrepaal, E.: Decadal warming causes a consistent and persistent shift from heterotrophic to autotrophic respiration in contrasting permafrost ecosystems, Global Change Biol., 21, 4508-4519, 2015.

Hicks Pries, C. E., Castanha, C., Porras, R. C., and Torn, M. S.: The whole-soil carbon flux in response to warming, Science, 355, 1420-1423, 2017.

Hicks Pries, C. E., Sulman, B. N., West, C., O’Neill, C., Poppleton, E., Porras, R. C., Castanha, C., Zhu, B., Wiedemeier, D. B., and Torn, M. S.: Root litter decomposition slows with soil depth, Soil Biol. Biochem., 125, 103-114, https://doi.org/10.1016/j.soilbio.2018.07.002, 2018.

Hicks Pries, C., Angert, A., Castanha, C., Hilman, B., and Torn, M.: Blodgett Forest CA Warming Experiment Soil Gas Well Data March 2014 to June 2017, Terrestrial Ecosystem Science at Berkeley Lab, Berkeley, CA, USA, https://doi.org/10.15485/1596312, 2020.

Hilman, B. and Angert, A.: Measuring the ratio of $\mathrm{CO}_{2}$ efflux to $\mathrm{O}_{2}$ influx in tree stem respiration, edited by: Ryan, M., Tree Physiol., 36, 1422-1431, 2016.

Hockaday, W. C., Gallagher, M. E., Masiello, C. A., Baldock, J. A., Iversen, C. M., and Norby, R. J.: Forest soil carbon oxidation state and oxidative ratio responses to elevated $\mathrm{CO}_{2}$, J. Geophys. Res.-Biogeo., 120, 1797-1811, https://doi.org/10.1002/2015JG003010, 2015.

Hopkins, F. M., Torn, M. S., and Trumbore, S. E.: Warming accelerates decomposition of decades-old carbon in forest soils, P. Natl. Acad. Sci. USA, 109, 1753-1761, https://doi.org/10.1073/pnas.1120603109, 2012.

Keeling, R. F.: Measuring correlations between atmospheric oxygen and carbon dioxide mole fractions: A preliminary study in urban air, J. Atmos. Chem., 7, 153-176, https://doi.org/10.1007/BF00048044, 1988.

Keeling, R. F., Piper, S. C., and Heimann, M.: Global and hemispheric $\mathrm{CO}_{2}$ sinks deduced from changes in atmospheric $\mathrm{O}_{2}$ concentration, Nature, 381, 218-221, https://doi.org/10.1038/381218a0, 1996.

Keiluweit, M., Nico, P. S., Kleber, M., and Fendorf, S.: Are oxygen limitations under recognized regulators of organic carbon turnover in upland soils?, Biogeochemistry, 127, 157-171, https://doi.org/10.1007/s10533-015-0180-6, 2016.

Kleber, M. and Reardon, P.: Biopolymers and Macromolecules, in Encyclopedia of Engineering Geology, edited by: Bobrowsky, P. and Marker, B., Springer International Publishing, Cham., 1-5, 2017. 
LaRowe, D. E. and Van Cappellen, P.: Degradation of natural organic matter: A thermodynamic analysis, Geochim. Cosmochim. Ac., 75, 2030-2042, https://doi.org/10.1016/j.gca.2011.01.020, 2011.

Liptzin, D., Silver, W. L., and Detto, M.: Temporal Dynamics in Soil Oxygen and Greenhouse Gases in Two Humid Tropical Forests, Ecosystems, 14, 171-182, https://doi.org/10.1007/s10021-0109402-x, 2011.

Masiello, C. A., Gallagher, M. E., Randerson, J. T., Deco, R. M., and Chadwick, O. A.: Evaluating two experimental approaches for measuring ecosystem carbon oxidation state and oxidative ratio, J. Geophys. Res., 113, G03010, https://doi.org/10.1029/2007JG000534, 2008.

Massman, W. J.: A review of the molecular diffusivities of $\mathrm{H}_{2} \mathrm{O}$, $\mathrm{CO}_{2}, \mathrm{CH}_{4}, \mathrm{CO}, \mathrm{O}_{3}, \mathrm{SO}_{2}, \mathrm{NH}_{3}, \mathrm{~N}_{2} \mathrm{O}, \mathrm{NO}$, and $\mathrm{NO}_{2}$ in air, $\mathrm{O}_{2}$ and $\mathrm{N}_{2}$ near STP, Atmos. Environ., 32, 1111-1127, 1998.

Melillo, J. M., Steudler, P. A., Aber, J. D., Newkirk, K., Lux, H., Bowles, F. P., Catricala, C., Magill, A., Ahrens, T., and Morrisseau, S.: Soil warming and carbon-cycle feedbacks to the climate system, Science, 298, 2173-2176, 2002.

Melillo, J. M., Frey, S. D., DeAngelis, K. M., Werner, W. J., Bernard, M. J., Bowles, F. P., Pold, G., Knorr, M. A., and Grandy, A. S.: Long-term pattern and magnitude of soil carbon feedback to the climate system in a warming world, Science, 358, 101105, https://doi.org/10.1126/science.aan2874, 2017.

Merchant, A., Tausz, M., Keitel, C., and Adams, M. A.: Relations of sugar composition and $\delta^{13} \mathrm{C}$ in phloem sap to growth and physiological performance of Eucalyptus globulus (Labill), Plant Cell Environ., 33, 1361-1368, https://doi.org/10.1111/j.13653040.2010.02143.x, 2010.

Neidhardt, F. C.: Chemical composition of Escherichia coli, Escherichia coli and Salmonella typhimurium: cellular and molecular biology, 3-6, 1987.

Phillips, C. L., Bond-Lamberty, B., Desai, A. R., Lavoie, M., Risk, D., Tang, J., Todd-Brown, K., and Vargas, R.: The value of soil respiration measurements for interpreting and modeling terrestrial carbon cycling, Plant Soil, 413, 1-25, https://doi.org/10.1007/s11104-016-3084-x, 2017.

Phillips, R. P., Erlitz, Y., Bier, R., and Bernhardt, E. S.: New approach for capturing soluble root exudates in forest soils, Funct. Ecol., 22, 990-999, https://doi.org/10.1111/j.13652435.2008.01495.x, 2008.

R Development Core Team: R: A language and environment for statistical computing, R Foundation for Statistical Computing, Vienna, Austria, available at: http://www.R-project.org (last access: 3 June 2020), 2019.

Randerson, J. T., Masiello, C. A., Still, C. J., Rahn, T., Poorter, H., and Field, C. B.: Is carbon within the global terrestrial biosphere becoming more oxidized? Implications for trends in atmospheric $\mathrm{O}_{2}$, Glob. Change Biol., 12, 260-271, https://doi.org/10.1111/j.1365-2486.2006.01099.x, 2006.

Rasmussen, C., Torn, M. S., and Southard, R. J.: Mineral assemblage and aggregates control carbon dynamics in a California conifer forest, Soil Sci. Soc. Am. J., 69, 1711-1721, 2005.

Rumble, J.: CRC Handbook of Chemistry and Physics, 100th Edn., CRC Press, 1554 pp., 2019.

Saglio, P. H. and Pradet, A.: Soluble Sugars, Respiration, and Energy Charge during Aging of Excised Maize Root Tips,
Plant Physiol., 66, 516-519, https://doi.org/10.1104/pp.66.3.516, 1980.

Scagel, C. F. and Andersen, C. P.: Seasonal changes in root and soil respiration of ozone-exposed ponderosa pine (Pinus ponderosa) grown in different substrates, New Phytol., 136, 627-643, 1997.

Seibt, U., Brand, W. A., Heimann, M., Lloyd, J., Severinghaus, J. P., and Wingate, L.: Observations of $\mathrm{O}_{2}: \mathrm{CO}_{2}$ exchange ratios during ecosystem gas exchange, Global Biogeochem. Cy., 18, GB4024, https://doi.org/10.1029/2004GB002242, 2004.

Severinghaus, J. P.: Studies of the terrestrial $\mathrm{O}_{2}$ and carbon cycles in sand dune gases and in Biosphere 2, PhD thesis, Columbia University, 1995.

Theenhaus, A., Maraun, M., and Scheu, S.: Substrate-induced respiration in forest and arable soils measured by $\mathrm{O}_{2}$ microcompensation: moisture conditions and respiratory qoutient, Pedobiologia, 41, 449-455, 1997.

Torn, M. S., Lapenis, A. G., Timofeev, A., Fischer, M. L., Babikov, B. V., and Harden, J. W.: Organic carbon and carbon isotopes in modern and 100-year-old-soil archives of the Russian steppe, Global Change Biol., 8, 941-953, https://doi.org/10.1046/j.13652486.2002.00477.x, 2002.

Trumbore, S.: Age of soil organic matter and soil respiration: radiocarbon constraints on belowground C dynamics, Ecol. Appl., 10, 399-411, 2000.

Tückmantel, T., Leuschner, C., Preusser, S., Kandeler, E., Angst, G., Mueller, C. W., and Meier, I. C.: Root exudation patterns in a beech forest: Dependence on soil depth, root morphology, and environment, Soil Biol. Biochem., 107, 188-197, https://doi.org/10.1016/j.soilbio.2017.01.006, 2017.

Worrall, F., Clay, G. D., Masiello, C. A., and Mynheer, G.: Estimating the oxidative ratio of the global terrestrial biosphere carbon, Biogeochemistry, 115, 23-32, https://doi.org/10.1007/s10533013-9877-6, 2013.

Yin, H., Li, Y., Xiao, J., Xu, Z., Cheng, X., and Liu, Q.: Enhanced root exudation stimulates soil nitrogen transformations in a subalpine coniferous forest under experimental warming, Global Change Biol., 19, 2158-2167, https://doi.org/10.1111/gcb.12161, 2013.

Zhalnina, K., Louie, K. B., Hao, Z., Mansoori, N., da Rocha, U. N., Shi, S., Cho, H., Karaoz, U., Loqué, D., Bowen, B. P., Firestone, M. K., Northen, T. R., and Brodie, E. L.: Dynamic root exudate chemistry and microbial substrate preferences drive patterns in rhizosphere microbial community assembly, Nat. Microbiol., 3, 470-480, https://doi.org/10.1038/s41564-018-0129-3, 2018.

Zhang, J., Quay, P. D., and Wilbur, D. O.: Carbon isotope fractionation during gas-water exchange and dissolution of $\mathrm{CO}_{2}$, Geochim. Cosmochim. Ac., 59, 107-114, https://doi.org/10.1016/0016-7037(95)91550-D, 1995.

Zuur, A., Ieno, E. N., Walker, N., Saveliev, A. A., and Smith, G. M.: Mixed Effects Models and Extensions in Ecology with R, 2009 Edn., Springer, New York, NY, 580 pp., 2009. 